\title{
IMPACT OF DETERGENT ON OXYGEN CONSUMPTION IN CHANNA PUNCTATUS
}

\author{
DHAIRYASHIL V. AHIRRAO AND ASHWINI B. PAWAR \\ P G Department Of Zoology, S.S.V.P.S.L.K. Dr. P. R.Ghogrey Science College, Dhule. \\ EMAIL : dv2ahirrao@gmail.com
}

Communicated : 13.12.18

Accepted : 19.01.19

Published: 30.01.19

\begin{abstract}
Use of detergents is increased day by day by human being and most of the detergents degrade very slowly in water body i.e. they remain in the aquatic system for longer time. Pollution of the water bodies will create physiological stress on the aquatic fauna. Among various forms of pollution in water bodies, detergent pollution has an immediate and detrimental effect. Channa punctatus, a common fresh water fish was used in our study to determine the effect of detergent pollution on the fish's breathing. Three different concentrations of a popular brand of detergent were prepared and the amounts of Dissolved Oxygen consumed by fishes exposed to the detergent were determined using Winkler's method. Present study demonstrated that Dissolved Oxygen consumption in Channa punctatus increases in the presence of detergent. This is due to the stress caused by the detergent on the normal physiological activities of the fish. Draining of domestic sewage containing detergents into water bodies adversely affect its aquatic fauna.
\end{abstract}

Key words :- Channa punctatus, Detergent, Dissolved Oxygen, Fresh water, Stress

\section{INTRODUCTION:}

Detergents are used in all households for washing purposes and in almost all households of domestic sewage are dumped into nearby water bodies. Detergents are not fully degraded even after sewage treatment and their discharge into the river cause serious pollutions problems. Detergents can also be wetting agents which lower the surface tension of water and act as clearing agents. Enzymes present in detergent cause several types of allergies. Phosphate in detergents favors the growth of algae which uses up most of the available oxygen in the water causing the death of aquatic organisms (Dara, 1993).

Use of detergents are indiscreetly increased day by day by human as washing the cloth, vehicles, and most of the detergents does not degrading easily or they degrade very slowly in water body, it means, they remain in the aquatic system for longer time. They enter in the food chain of aquatic animals or absorbed through the gills or through the skin of the aquatic animals. Detergents are organic compounds, which exists at phase boundaries, where they are of three types anionic, cationic and non-ionic detergents (Walker et al., 2001). Detergents which discharged in the water they may change $\mathrm{pH}$, total alkalinity, free $\mathrm{CO}_{2}$, DO and also affect the rate of photosynthesis and lead to eutrophication (Najam et al., 2010). Thus it has toxic effects on aquatic animals like fishes.

Detergents that contain phosphate are highly caustic and surfactant detergents are very toxic.
They are widely used in daily activities and these detergents cause excess frothing and growth of floating aquatic weeds (eutrophication) on the water surface, affecting aeration and quality of fresh water. This adversely affects the physiological and biochemical processes of fish, number of factors such as temperature, $\mathrm{pH}$, salinity, turbidity and so on affecting the dissolved oxygen content as well as the oxygen consumption by the fishes. The synthetic detergents can alter $\mathrm{pH}$ and salinity of receiving freshwater bodies, which affect oxygen consumption by aquatic organisms including fishes (Chandanshive, 2013 and 2014).

In the present investigation a common freshwater fish, Channa punctatus was selected to determine the effect of detergent pollution on the fish's breathing.

\section{MATERIALS AND METHODS :-}

For the present investigation fishes (Channa punctatus) were collected from fish hatchery, MIDC, Dhule. Young fishes averaging $10 \mathrm{gm}$ weight were selected. Water samples for the experiment were collected from aquarium tank. Four different concentrations $(50$ ppm, 100 ppm, $150 \mathrm{ppm}, 200 \mathrm{ppm}$ ) of the popular brand of detergent (Surf excel) were prepared in the sample water. Transferred the fishes each into four jars with the above said concentration of the detergents and kept for one hour. Similarly four jars of that different concentration of detergents were kept as controls. After one hour, water samples were collected and estimated their DO content by Winkler's method. Difference between 
the amounts of DO in the sample with only detergent and that with both detergent and fish gave the amount of DO consumed by the fish for the particular concentration of detergent was calculated.

\section{RESULT AND DISCUSSION:}

Dissolved oxygen in the water (taken from aquarium) was estimated before adding the detergent or introducing the fish of nearly $10 \mathrm{gm}$ (Channa punctatus) and the values averaged $9.68 \mathrm{mg} / 1$. This value was taken as the control. Dissolved oxygen concentration indicated that the water samples collected for experiment contain sufficient amount of dissolved oxygen for the survival of the fish. As the sample was treated with $50 \mathrm{ppm}, 100 \mathrm{ppm}, 150 \mathrm{ppm}, 200 \mathrm{ppm}$ of detergent for a time period of 1 hour, the dissolved oxygen content showed a decreasing trend ranging from $9.48 \mathrm{mg} / 1,9.23 \mathrm{mg} / 1,8.89$ $\mathrm{mg} / 1$ and $8.12 \mathrm{mg} / 1$ (Table 1 ).

Detergents are composed of complex phosphates which eventually breakdown into phosphates usable by aquatic plants. The use of detergents has been responsible for the increase in the phosphorous in sewage effluents. On treating the fishes with different concentrations of detergents they exhibited a state of inactive nature with an in increase in the rate of breathing with the secretion of mucous.

Oxygen consumption rate in the control bottle was $2.69 \mathrm{mg} / 1$. At a concentration of $50 \mathrm{ppm}$, the oxygen consumption rate was $3.20 \mathrm{mg} / 1$. The rate was shown in an increasing trend of $3.85,4.77$, $4.90 \mathrm{mg} / 1$ respectively for concentrations $100,150,200 \mathrm{ppm}$. Above result showed that concentration fish exhibited a decline in the rate of survival. Oxygen consumption with respect to the gram body weight also exhibited an increase in the consumption rate with respect to an increase in the concentration of detergent.

The results showed decreased rate of oxygen consumption in the fish Channa punctatus that may be due to direct effect of detergent. The control showed maximum respiratory metabolism (Table 1 Fig 1). The present study was found to be in consistent with the work of Chandanshive (2013 and 2014) in fresh water fish Mystus montanus, Mathew et. al. (2013) and Rajan (2015) on Anabas testudineus due to the effect of detergent, which revealed that oxygen consumption decreased significantly with each progressive rise in detergent concentration.

\section{ACKNOWLEDGEMENT :-}

The authors are grateful to the President, Chairman, Secretary and Principal of S. S. V. P. S. L. K. Dr. P. R. Ghogrey Science College Dhule.

\section{REFERENCES:-}

APHA (1985): Standard methods for the examination of the water and waste water, $16^{\text {th }}$ edition.

Chandanshive N.E. (2013): Studies on toxicity of detergents to Mystus montanus and change in behaviour of fish. Journal of Animal, Veterinary and Fishery Science. 1(9):14-19.

Chandanshive N.E. (2014): Effects of different Concentrations of Detergents on Dissolved Oxygen Consumption in fresh water fish Mystus montanus. Int. Res. J. Environment Sci. Vol. 3(8), 1-5.

Dara S.S. (1993): A textbook of environmental chemistry and pollution. S. Chand and Co. Ltd., New Delhi

Mathew Emi, Sunitha P.T., Philip Litto Thomas (2013): Effect of Different Concentrations of Detergent on Dissolved Oxygen Consumption in Anabas testudineus. IOSR Journal of Environmental Science, Toxicology and Food Technology (IOSRJESTFT) Vol. 5 (3), PP 01-03.

Rajan Divya S. (2015): An evaluation of the effect of a detergent on dissolved oxygen consumption rate of Anabas testudineus. International Journal of Fisheries and Aquatic Studies; 2(6): 46-48.

Topale P.S., Ghaware A.U. and Jadhao R.G. (2013): Effect of Detergent Tide on Paratelphusa jacquemontiil (Rathbun) Freshwater Crab from Vidarbha Region. Int. Res. J. of Science and Engineering, Vol.1 (1): 10-12.

Walker C.H., Sibly R.M., Hopkin S.P., Peakall D.B. (2001): Principles of Ecotoxicology. 2nd edition. 


\begin{tabular}{|c|c|c|c|c|}
\hline $\begin{array}{c}\text { Concentration } \\
\text { of Detergent } \\
\text { (ppm) }\end{array}$ & $\begin{array}{l}\text { Dissolved Oxygen } \\
\text { (mg/1) }\end{array}$ & $\begin{array}{c}\text { Dissolved Oxygen } \\
\text { (mg/1) (Fish and } \\
\text { Detergent) }\end{array}$ & $\begin{array}{l}\text { Dissolved } \\
\text { Oxygen } \\
\text { consumed by } \\
\text { fish (mg/1) }\end{array}$ & $\begin{array}{c}\text { Oxygen } \\
\text { consumption } \\
\text { (mg/1/hr/g body } \\
\text { weight of Fish) }\end{array}$ \\
\hline 0 & 9.68 & 6.99 & 2.69 & 0.26 \\
\hline 50 & 9.48 & 6.28 & 3.20 & 0.32 \\
\hline 100 & 9.23 & 5.38 & 3.85 & 0.38 \\
\hline 150 & 8.89 & 4.12 & 4.77 & 0.47 \\
\hline 200 & 8.12 & 3.22 & 4.90 & 0.49 \\
\hline
\end{tabular}

Table 1 : Oxygen Consumption of Channa punctatus exposed to various concentration of detergent (Surf excel).

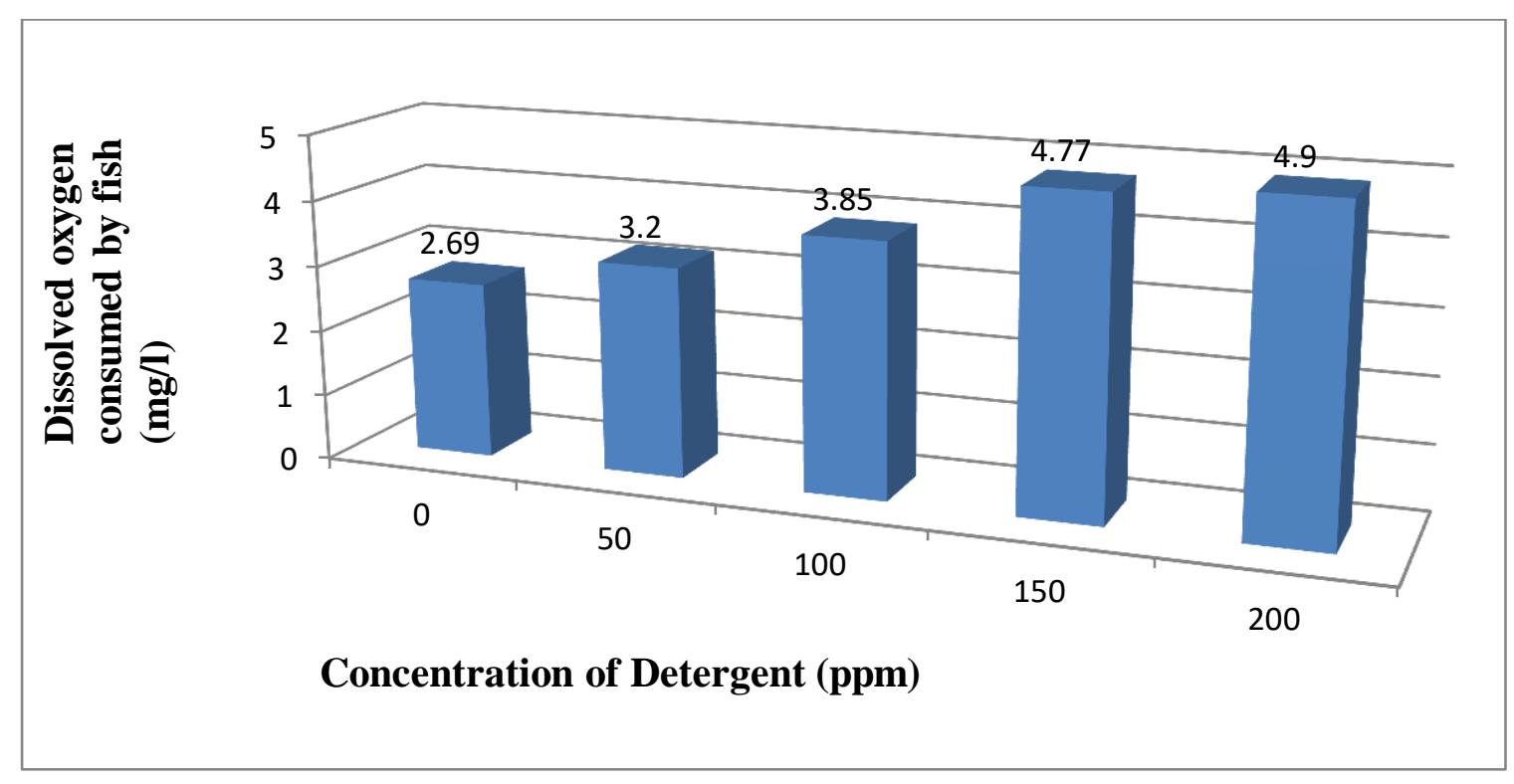

Fig. 1 : Oxygen Consumption of Channa punctatus exposed to various concentration of detergent (Surf excel). 